\title{
Nepali Hindu Women's Thorny Path to Liberation
}

\author{
Raj Kumar Dhungana* \\ School of Education, Kathmandu University, Lalitpur, Nepal
}

\begin{abstract}
This article explains how Nepali Hindu women's oppressive position was created in the past and how they are still struggling for their full liberation - mukti. It also reflects that Hindu women's long journey towards freedom and equality has been moving through a thorny path. Deriving mainly from literatures, this paper discusses how Nepali Hindu women's identity 'Aimai' was constructed and how, through their continuous struggle, they are getting better condition as dignified 'Mahila' yet far from their reach to the position of fully liberated women -mukta mahila.
\end{abstract}

Keywords: Hindu women; patriarchy; oppression; liberation; Mukti; Gyana

The oppressed position of women has been significantly discussed in many fronts in South Asia but the critical analysis on the role of Hinduism in the construction of egalitarian or gendered society is less discussed in academia. This paper focuses on explaining how the Hindu women are trapped into oppression and how they are struggling mainly through their action and education (Karma and Gyana) for achieving their full liberation or mukti ${ }^{1}$. It also discusses how patriarchic Hinduism created oppressed status of women and further explains how Hindu women's oppressive position is constructed and maintained in Nepali society. In addition, it analyses why Hindu women are still oppressed despite their continuous struggle, supplemented by education, against the patriarchic system. It begins with how most of the religions are gendered to some extent and goes into the deeper discussion on the patriarchic form of Hinduism constructing women's position in Nepal.

\section{Gendered Dimension of Religion and Culture}

Religion is influential in all cultures. Sachedina (2003) remarked "Throughout history, women have been denied basic human rights, through religiously imposed restrictions or economically designed exploitation and manipulation of their position in family and in society" (p. 11). The consequences of male domination are reflected in religion as the western religion comes from the men's worldview (Adams \& Sydie, 2009, p. 276). Even today, there is no voting right for women in Vatican City - a holy city of Christians. Till 2011, women did not have voting rights in Saudi Arabia, the country with a holy city of Muslim - Mecca.

Similarly, the Quran has clearly positioned men in one position higher than women (Falahi, 2008, p. 60). The Quran inscribed, 
Men are the protectors (545) and maintainers of women, because Allah has given the one more (strength) than the other, and because they support them from their means.

Therefore the righteous women are devoutly obedient, and guard in (the husband's) absence what Allah would have them guard (546). (as cited in Ali, n.d., p. 54)

Christianity has also contributed to construct a gendered society. Pottenger (2010) argued that the Biblical verse "wives should submit to their husband" (5:22-33) is used to mistreat women in Christianity. Similarly, the traditional Jewish societies are separated by sex where men spend time in reading Hebrew prayer, women preparing ritual foods (Sered, 2011) and therefore the women's access to knowledge has been restricted. Similarly, in Buddhism, despite Buddha's egalitarian principle, monks institutionalized their right to leadership in all sangha matters, and nuns were permanently relegated to a lower level in the religious hierarchy (Barnes, 2002, pp. 59-60). In a similar vein, female infanticide is also practiced in Chinese society, which is largely guided by Confucian tradition, where women's value was depicted as lower than men (Mosher, 2007). Moreover, discrimination against women is also found in other religions like Jainism, Shikhism, Zarathushti, and Baha'i (Sharma, 2002). Quite alike, the situation of women in Hinduism is not an exception.

Hinduism is not a religion but it is - sanatana- the tradition and way of life (Sen, 1961). The religion, rituals and practices are always interwoven. However, the religion has set certain rituals which are further interpreted by the priests/pundits in a form of language, idioms, myths, metaphors etc. When the religion is practiced by people, it makes a way of life or culture. In this connection, E. B. Taylor has said that culture is "that complex whole which includes knowledge, belief, art, law, morals, custom, and any other capabilities and habits acquired by man as a member of society (as cited in O'Neil, 2006). The social concept about Hinduism and women's position in Hindu society is shaped by various religious texts like the Manusmriti (the codes for Hindu); the Swasthani (story of Lord Shiva and a part of the Skandapurana), the Chanakya Niti (Code of rulers), and Sanskrit epics the Ramayana and the Mahabharata among others. Here I have presented ideas from some of these influential Hindu scripts that shaped women's position in Nepali society. The practices, codes, values and belief systems rooted in Hinduism determined the meaning of good and bad, right or wrong, master and subordinate varied in different era. According to Young (2002), women's situation during the Rig Veda ${ }^{2}$ ic Period (1200-800 BCE) was more egalitarian, less hierarchical (which is true still in many other societies) (p. 5). Similarly, in the Rig Vedic period, men's authority to perform daily rituals was transferable to wives (Jha, 2007). This pure Vedic Hinduism was distorted and manipulated over the time and created a dogmatic form of Hinduism which is the Patriarchic Hinduism which positioned women into the lower strata of social order than men. Broadly, this distorted Hinduism is fostered by elites and rulers in Nepal and other countries (Young, 2002). 
Hindu is the major religion in India, Nepal and Mauritius; similarly it is the third largest religion - 15\% of the total World Population after Christian and Muslim - (Indian Express, December 19, 2012). Through its religious texts of shruti (that which is heard) and smriti (that which is remembered) this religion is guiding the Hindus of Nepal, India and other places (Young, 2002). There are Hindus, Buddhists, Christians, Muslims and people following other religions living in Nepal. However, Population and Housing Census of 2011 has shown that about 81 per cent of the total population is Hindu (Central Bureau of Statistics [CBS], 2012]. Moreover, because of the large majority of Hindu population and also because of state policy and power Nepali society is largely influenced by the Hindu way of life (Awasthi, 2004, p. 89). As a result of this influence, non-Hindu women are also gendered in Nepal and therefore this article broadly covers the issue of women living in Hindu influenced Nepali society. The cultural assimilation of other non-Hindu into Hindu religious community is traceable via legal and development actions led by Hindu Kings including their supporters who tried to construct a unified national identity through their rule over heterogeneous population (Pettigrew \& Shneiderman, 2004). Even within the Hindu religion, women are among the oppressed ${ }^{3}$ groups in Nepal, and also the gender gap is highest among three Hindu majority countries (World Economic Forum, 2013). This shows that the issue of women's liberation from the oppressed position in Nepali Hindu society is very prominent.

\section{Construction of Hindu Women as the Oppressed Aimai}

Women's journey towards emancipation, freedom and equality has been facing various ups and downs that are manifested in the form of religious practices, cultures and traditions. Historically, Hindu women have been fighting for their mukti (greater freedom) which was not very smooth and easy. Over four thousand years of journey, the meaning, traditions and practices of Hinduism has been changing; and consequently the women's conditions and positions vary even within the Hindu community in different times. Literature has shown that Nepali women have been suppressed and oppressed from the time immemorial (Shrestha, 2011). Based on everyday gendered practices of Nepali society and as are often reflected in literature, media and my worldview, I would use the term Aimai to denote their oppressed position.

Young (2002) divided the history of Hinduism into five periods: Rig Vedic Period (1200800 BC), Middle and Late Vedic Period (1200-400 BC), Classical Period (400 BC-400 AD), Medieval to Early Modern Period (400-1950), and Modern Period (1950 to now) (pp. 4-17). In different periods, Hinduism gradually changed through its internal and external reasons. The influences from Islam and Christianity and also from Buddhism, Jainism and Sikhism are some of the external reasons that contributed to bring changes in Hinduism (Sen, 1961). In the beginning of the Rig Vedic ideology, Hinduism promoted semi-egalitarian values where women were free to choose their mate as in the other non-Hindu communities (p. 6). 
During the Classical and Early Modern Period, orthodox religious elites worsen women's situation by creating, reinforcing and institutionalizing restrictions mainly through various important religious texts like the Manusmriti (the codes for Hindu); the Swasthani (the story of Lord Shiva that is recited for 30 days in the month of Magh in the Hindu households), and major Hindu epics like the Ramayana and the Mahabharata. For instance, the Ramayana presented the story of Sita, who, left her palace and chose to stay with her husband in jungle for 14 years, was abducted by Ravana, a demon. When Ram freed her from war he asked Sita to prove her purity through Aagnipariksha (a purity test by jumping onto the fire). Even after being proven pure, Ram exiled Sita to the jungle (Gewali, 1954). The same Sita was portrayed as the most ideal wife for the Hindus (Young, 2002, p. 12). Primarily, the Puranas and the Manusmriti were influential during the Classical and Early periods which have set dual positions (Halder \& Jaishankar, 2009). On duality, Shah (2004) argued, "In one hand, power of motherhood is symbolized in a form of creator - mata - on the other hand, they are controlled to protect pre-sexual sacredness" (p. 88). Halder and Jainshankar (2009) also argued that, in one hand, the Puranas, mythological stories, have described Goddess as Shakti (Goddess of universal power), Mahalaxmi (Goddess of wealth), and Mahasaraswati (Goddess of Knowledge); on the other hand, it placed women below the status of Sudra, the lowest strata of Hindu society (p. 665). The Pauranic story also portrayed women as the predisposing subject of sin given by creator. Bennett (2002) explained that the concept of purity during menstrual cycle is established by mythical stories that menstrual blood is a source of sin thrown by Creator (Brahma) (pp. 215-216). The Rig Vedic concept of this 'purity' is used to confine women's sexuality in Hindu tradition (Chawala, 1992). Therefore, Hindu women are recognized as polluted during menarche and childbirth (Shah, 2004). It means purity is the major concept used to confine women's sexuality in Hindu tradition. The concept of impurity during menstrual periods has been institutionalized in Nepali Hindu society which is locally called na chune, untouchable (Bennett, 2002, p. 215). For institutionalizing this, polluted image of women is much discussed and brought into practice in Hindu society. However, most people may not be aware that women are restricted even to see the goddess inside the worship rooms of the Hindu households. Moreover, women are also excluded from certain auspicious days like Durga Puja (Thapa, 2010).

Manusmriti ${ }^{4}$ - the Hindu Code is another major Hindu document that has defined women's position in society. It is commonly held that where women are honored, there the gods are pleased; on the contrary, it is also mentioned that Her Father protects (her) in childhood, her husband protects (her) in youth, and her son protects (her) in old age; a women is never fit for independence. (Manusmriti, 3.56)

These religious codes and principles might have their contextual meanings but are not universally applicable for all generations. Originally the Puranas and Manusmriti might have aimed at protecting women from fear, protecting their virginity, and controlling them against 
their freedom. Particularly, Manusmriti is criticized for being not appropriate to the modern and civilized world (Singhal, 2006). Late Vedic elite society was much more ritualized than the early period (Young, 2002, p. 6). In this period, women were less trusted than men to perform any Vedic rituals which are cemented in the present Hindu society of Nepal through metaphors like Aimai Ko Rudraghanti Hudaina [Women are not trustworthy]. The Chanakya Niti [Code for rulers], one of the influential Hindu codes for rulers during Medieval as well as in classical period (400 BC-400 AD), says, "Do not put your trust in rivers, men who carry weapons, beasts with claws or horns, women, and members of a royal family" (Chanakya Niti Darpan, 1.15). Consequently, Hindu women were taken as weak, vulnerable and untrustworthy, thus their access to information and participation in family matters was denied. In this way, to control women, the practices of wife battering, domestication, restriction of their movement were institutionalized in the form of patriarchy. Restriction over movement is another major thorn created by patriarchic Hinduism. Chanakya in his Chanakya Niti Darpan stated, "The king, the brahman, and the ascetic yogi who go abroad are respected; but the woman who wanders is utterly ruined" (6.4). In this way, prohibiting women from being exposed and from interacting with outsiders was also institutionalized.

In the Medieval to Early Modern period (400 -1950), Hindu women's position was increasingly restricted and Sati-Pratha ${ }^{5}$ was one of such restrictive practices. Lohani-Chase (2008) explained that, "In Sanskrit, Sati means the one who "follows her husband" in everything, including death. Now, sati is usually used as a noun, which also signifies a living woman devoted to her husband, not only the one who dies on the pyre (p. 31). Lohani-Chase (2008) further argued,

Although much research is needed to find out how sati worked in Nepal and what kind of agency women had, it is clear that sati existed. Though Manadeva (464-505 AD) earned great affection for his good deeds and for preventing his mother from throwing herself on her husband's funeral pyre, sati lingered among upper caste Hindus into the twentieth century. (p. 31)

Before Rana Prime Minister Chandra Samsher (1901-1929) outlawed in 1924, SatiPratha was in practice among the orthodox Hindu families. It was a powerful example of controlling women's sexuality through a brutal practice that occurs through predisposition (Kondos, 2004, pp. 61-67). The concept of sati is not erased from Hindu culture as it is still retaining in day to day language in a different meaning - as a dedicated wife.

Acharya (2012) argued that after the unification of Nepal, women were historically discriminated under Hindu rulers. King's 1962 Constitution intensified the discriminatory practices against women and even the 1990's democratic political change failed to eliminate these practices. Accordingly, women remained and still remain a second class citizen even 
legally, despite the constitutional declaration of formal political equality and no discrimination on the basis of "caste, ethnicity, sex and religion" (Acharya, 2012, pp. 3-4).

Language and idioms play an important role to sustain and reinforce women's oppression and restrictions. The modes of cultural transfer from one generation to another are powerful in their ability to influence their audience (Chu, 1996). In the Nepali context such idioms and metaphors are used to discourage women and remind them of their current position. "Aimai is made to go to other's house [Aimai vaneko Arkako Ghar Jane Jat]" is one such common metaphor in Hindu's communities. Malla (2001) has listed some more gendered metaphors;

- The birth of a son paves way to heaven (Chhora paye swarga jaane)

- If a son is born, it is celebrated by sacrificing a goat, if it's a daughter, a pumpkin is enough (Chhora paye khasi, Chhori paye Pharsi)

- A wife is the dust of the foot (Srimati bhaneko paitalako dhulo ho)

- A daughter as an auspicious gift (Kanya Daan)

- If a daughter dies, we can say she has been married into a rich home (Chhori mari, thulo ghar pari)

These types of myths, idioms and metaphors helped cementing patriarchic cultural-social traditions which are rooted in patriarchic Hinduism. As a result, Nepali women are straitjacketed and domesticated. They are constrained to perform certain religious activities and to participate in political, economic and social activities (Lawoti, 2010, p. 31).

'Hindu women' is not a homogeneous community as it represents the high caste royal women to the extremely poor Dalit ${ }^{6}$ women who are presented as impure in the society and therefore they face multiple oppressions. Likewise, Hindu women's movement towards mukti also varies in terms of caste, class, education, and age among others. However, the oppressive socio-cultural and customary practices are largely universal for all Nepali Hindu women. Such restrictions clearly show women's 'Aimai' position in Hindu society. In this context, women are struggling against the patriarchic system which is further discussed from the perspective of mukti, a classical perspective of liberation.

\section{Mukti, a Theoretical Perspective on Women's Liberation}

Hindus believe that one may reach the god (achieve mukti from worldly troubles) through work (karma), meditation and knowledge (gyanaa), or through devotion (bhakti) (Sen, 1961). As men, after their death, Hindu women also want mukti (also called mokshya), the supreme level of liberation and the world of peace where there is "No need to be born again" (Bennett, 2002, p. 39). A Hindu holy book, the Geeta, inscribed, "Up to Brahma's realm Arjuna, the worlds come round again and again; but once I have been reached, son of Kunti, rebirth is 
finished" (8.16). I have taken the idea of Mukti as a metaphor to conceptualize women's movement for liberation with equality and dignity.

The concept of bhakti provided some leverage to women by allowing them to love Gods besides their husbands and in some instances they are also allowed to remain unmarried being devotees to the gods (Young, 2002, p. 17). Further, karma and gyana significantly contributed to women's journey towards mukti. Through karma, women have been fighting to create a new and mukta or the liberated and dignified position. It implies that women's liberation from patriarchy is the major milestone towards their mukti. "An emancipated population has access to legal rights. It is a formal type of equality, but does not necessarily reflect a social attitude or value of equality" (Stivachtis \& Georgakis, 2008, p. 2).Thus, Nepali women's desire for mukti is beyond legal rights as they need equal dignity and liberation from all forms of patriarchic thorns.

The two concepts, mukti and liberation are not mutually exclusive rather they represent a progression against women's oppression as depicted in gender oppression theory (Ritzer, 2000). Gender oppression theory argues that "women are oppressed, not just different from or unequal to, but actively restrained, subordinated, molded, and used and abused by men" ( $\mathrm{p}$. 450). Practices of oppression are different in different places and contexts. In early society, patriarchy was created by Hindu religious leaders to protect girls and women as and when needed as a part of collective moral duty (Ritzer, 2000, p. 90) but, in reality, it has been practiced differently than the original idea. Talking about the imposing nature of religion, Bordieu has argued,

Religion contributes to the (hidden) imposition of the principles of structuration of the perception and thinking of the world, and of the social world in particular, insofar as it imposes a system of practices and representations whose structure, objectively founded on a principle of political division, presents itself as the natural-supernatural structure of the cosmos. (as cited in Verter, 2003, p. 6)

The "everyday world" of women is problematized by sociologists by bringing the women's dissatisfactions of their daily life (Adams \& Sydie, 2009) and this paper has also echoed with this by questioning the Hindu women's present life using the Hinduized concept of mukti. Despite so many thorns in the Hindu culture, it is also true that women have not remained passive accepting all forms of oppression and discrimination. Then, questions arise, besides little effect from bhakti (devotion), how far is Nepali Hindu women's journey towards mukti progressed from gyana (wisdom fostered by modern education) and karma (doing their duty to resist against oppression), whether Hindu women's karma and gyana contribute to women's mukti or regression? These questions shape up the central course of further discussion. 


\section{A Journey From the Oppressed Women Towards the Liberated Women}

Despite the stronghold of patriarchic tradition, Hindu women are continuing their struggles against the oppression which has been clearly recorded since the beginning of 18th century, in the modern history of Nepal. In this regard, feminist proponents have engaged in debates concerning the utility of deconstruction and to understand how it can help feminists to move away the oppressive concept of woman (Khezerloo, 2002). In Nepal, the journey to women's mukti has been moving through their active karma - the socio-political action (Malla, 2011) and has been manifested in various political and social struggles. These struggles have been contributing to eroding the orthodox and thorny patriarchic context and increasingly gaining access to productive resources and favorable policies and participating in development realms (Shah, 2004). Nepali women's journey for coming out from the rooted enslavement and patriarchy is being manifested in social, political and economic realms which is further strengthened by the increased literacy of women. Whether Nepali women's struggle against patriarchy is focused on mukti or not could be an interesting discussion here. Dahal (2004) stated that, "The women's movement is a response to partly the Hindu code of law and partly gender discrimination rooted in religion, race, caste, sex, place of birth, etc. and the deep structural inequality embedded in traditional society" (p. 12). Explaining the purpose of Hindu women's movement, Dahal (2004) argued that women's movement in Nepal is basically against Hindu code and is also against the rooted gender discrimination. Women's movement for freedom- mukti has thus to be located in broader political movements as women's movements are very much aligned with the political struggles in Nepal.

The history of women's struggle for their freedom is not well documented in Nepal. Thapa (2012) depicted that women's bravery and karma - the great works - have been ignored by male historians. If history indeed is about all 'facts' and all 'events' then how could it fail to show the bravery of Rajendra Laxmi who once led Nepal's unification, or Lalit Tripura Sundari, the first woman who translated one section of the Mahabharata "Shanti Parba's Raj Dharma [King's Code]" into the Nepali language from Sanskrit. Similarly, Ms. Kamala, (the wife of warrior Balabhadra Kunwar) participated in the Nalapani Fort in AngloNepal war in 1814-16. Evidences show that there were dead bodies of women inside the Nalapani Fort which clearly shows that Nepali women fought against British Army in the History of Nepal (Onta, 1996). Similarly, Yogmaya (1860-1941) supposedly the first Nepali woman who organized and led a movement against adverse social practices, particularly those practices that were oppressive for women, and who moved people against the Rana regime. Likewise, there were Ambalika Devi, Lok Priya Devi, Chandrakala Devi, Mangaladevi, Divya Koirala and many other women who contributed to the arena of Nepali literature, art, and politics. Much of their lives have been excluded [or written very little] from the narratives of official records (Thapa, 2012). 
The sacrificial revolt of Yogmaya Neupane can be taken as the start of women's organized movement in Nepal. She is the first woman who dared to fight against the tyranny in Nepal for women's liberation. She is a classic example of Hindu women's Shakti - power to challenge the highly male dominated Rana regime by bringing the very prominent issue of good governance. On Yogmaya, Aziz (2001) stated that, "These village women called for justice for their people long before the women's rights and civil rights movements in the west" (p. xxv). Sangraula (May 4, 2011) also describes her story that she gave voice to the voiceless - women, lower castes, the exploited - when the entire country cowered to the Rana rulers. Yogmaya had two agenda, first about the monopoly of the Brahmin priests or Braminization of the Vedic egalitarian idea of Dharma and the second about the state's support to the distorted Hinduism. Aziz (2001) presented,

Yogmaya had a two-pronged agenda, not just one. Manamaya explained, "Her first target was our Brahminic system, propagated by Brahmin priests, that gives privileges to a few and makes rules that enslave the rest, and women of all castes. Her second object was our ruler, the Prime Minister, who along with his generals allowed corruption and inequality prevail. Our master, Shakti Yogmaya, showed us how these two evils are intertwined, and she feared neither." (p. 33)

She submitted a list of 268 points demands to the government in the name of "Satya Dharma Bhiksha" including the elimination of all injustice and suppression (The Women's CAUCUS of the Constituent Assembly, 2010, p. 12). Similarly, another strong lady with similar initial name Yogmaya Koirala established first women's organization, "Women Committee" in 1974 (Shrestha, 2011).

The Hindu women's movement was further supported by educational and political organizations. Padma Kanya School established by Chandrakanta Malla (Thapa, 2008) provided platform for girls to get education since 1945 and after that Rebenta Kumari Acharya established Aadarsha Mahila Sangh (Thapa, 2008). Similarly, Mangla Devi Singh, Punya Prava Devi Dhungana, Kamal Rana and Rohini Shah established political organizations for women i.e. Nepal's Women's Association, All Nepal Women's Association, Women Volunteer Services and Birangana Dal respectively. As a result, Nepali women influenced policy and acquired some legal rights "equality before law" which was enshrined in "Nepal Government Act-2004 B.S." which was also recognized by 1950 constitution (Neupane, 2004).

Nepali Congress party mobilized female college students (Ms. Kamaksha Devi Rana, Mrs. Hira Devi Tuladhar (Yemi), Ram Maya, Sadhana Adhikari, Sahana Pradhan, etc.) to show black flags to King Mahendra in 1961 as a political dissent (Shah, 2004, p. 113). Shah (2004) has noted that the term "Mahila" started to appear in Nepal since 1930s. The construction of "Mahila" was marked as distinct from other existing ways of identifying 
women. In 1951, targeting for political awareness, Kamakshya Devi and Sadhana Pradhan published 'Mahila Masik' (Women's Monthly) magazine (Thapa, 2008, pp. 6-7). Mahila referred to a modern female subject and its usage was probably influenced by the promotion of the "Bhadra Mahila" ideal by the Indian nationalists and Hindu reformers towards the end of the 19th Century (Shah, 2004). With the beginning of open political environment in the county in 1990, Hindu women started getting more chances to get into political arena using the reserved seats.

Women's participation in formal politics has increased in the post 1950s scenario in Nepal. In 1952, Sadhana Adhikari was elected the member of Kathmandu Municipality representing Nepal Women's Association (RSN, 2009). Though woman were not elected in 1959's election, the first Elected Prime Minister B. P. Koirala recognized the role of women in politics and government and therefore nominated Dwarika Devi Thakurati as the Deputy Minister for Health and Local Self-Governance (Joshi \& Rose, 1966, p. 314).

In 1992, Women Security Pressure Group in Leadership pressurized the government to include more women in politics and at the same year as the result of continued pressure from women and other agencies, the government signed the UN Convention against All forms of Discrimination (Women's Caucus, 2008). In mid 1990s, Maoist insurgency also contributed to bring new insights into women's agency through the embodiment of militancy and militarism (Lohani-Chase, 2008). It helped Nepali women to break the feudal patriarchal restrictive life of theirs, mainly for the more oppressed women like Dalit by providing them a chance to express their dissatisfaction against caste and gender based oppression (Pettigrew $\&$ Shneiderman, 2004). From the gender equality perspective, the Constituent Assembly Election (2008) made marked progress by including more than $30 \%$ women in the legislative body.

The women's participation in political activities has been increasing since the beginning of the 20th century in Nepal. Women's participation in political activities and their sociopolitical movement succeeded in enacting a semblance of property rights and increased the degree of representation in structures of local self-governance (Dahal, 2004). In each subsequent election, the number of women candidates being elected has increased. In the 1999 's local bodies' election in Nepal, the number of women emerged as leader was very high and also the number of elected women had increased significantly. Local Governance Act (1999) allocated a quota of 20 percent of seats for women in local bodies and Nepal's Interim Constitution (2007), Article 63(5) guarantees one third of the seats in the Constituent Assembly to women. These provisions were utilized by Nepali women. At the village level, 25 per cent of those women who stood for elections won (Karki, 2009) and the provision of 20 percent reserved seats was the major reason behind the improved women's participation (0\% in 1959 to $3.4 \%$ in 1991 and reached $32.8 \%$ in 2008) in local bodies. In general, 
women's participation in Nepali politics has been consistently growing with some exceptions. See Table 1 for details.

Table 1

Women's Position in Various Elections in Nepal

\begin{tabular}{|c|c|}
\hline Election & Results for women candidates \\
\hline $\begin{array}{l}1959 \text { Parliamentary } \\
\text { Election }\end{array}$ & $\begin{array}{l}\text { In the first Parliamentary elections of } 1959 \text {, the entire } 6 \text { women } \\
\text { candidate contesting in election lost where total } 109 \text { men were elected } \\
\text { (Suwal, 2013). }\end{array}$ \\
\hline $\begin{array}{l}\text { Rastriya Panchayat, } \\
1986 \text { (legislative) } \\
\text { Election }\end{array}$ & $\begin{array}{l}\text { Out of total } 140 \text { members of parliamentarians total } 3 \text { women were } \\
\text { elected in Rastriya Panchayat (Mongbay, 2013). }\end{array}$ \\
\hline Parliamentary, $1991^{7}$ & $\begin{array}{l}\text { In the first } 1991 \text { election out of } 205 \text { legislatives representatives only } 7 \\
(3.4 \%) \text { women were elected (Yemi, 2010). }\end{array}$ \\
\hline $\begin{array}{l}\text { Parliamentary and } \\
\text { Local Bodies, } 1999\end{array}$ & $\begin{array}{l}\text { In } 1999 \text { total } 12(5.85 \%) \text { of total } 205 \text { member of parliaments were } \\
\text { women and } 806(19.4 \%) \text { of total } 4146 \text { local elected representatives } \\
\text { were women (UNESCO, 2001). }\end{array}$ \\
\hline $\begin{array}{l}\text { Constituent Assembly, } \\
2008\end{array}$ & $\begin{array}{l}30 \text { out of } 240 \text { elected CA members were women. Total members of } \\
\text { CA including Proportionate Representative System was } 197 \text { ( } 32.77 \\
\text { percent) of the total } 601 \text { CA members (Election Commission, 2008). }\end{array}$ \\
\hline $\begin{array}{l}\text { Constituent Assembly } \\
2013^{8}\end{array}$ & $\begin{array}{l}\text { Out of total } 240 \text { elected candidates total } 10(4.1 \%) \text { candidates were } \\
\text { women. (Shahi, } 24 \text { Nov, 2013). }\end{array}$ \\
\hline
\end{tabular}

In the consistent increasing trend of women's political participation in local and legislative elections, the Constituent Election 2013 is an exceptional case. Reduction in the number of women candidates from 96 in 2008 to 77 by the three major political parties in 2013 CA Election is the major reasons of this regression (Pradhan, 2013). However, the lower number of elected women in CA has not significantly hampered the women's role in $\mathrm{CA}$ as there is a legal provision to include at least 50 percent of women in the Proportional Representation (PR) system established by law on Election to Members of the Constituent Assembly, 2007, Article 7. Low women representation in political parties [only 12.4 percent in central committee (RSN, 2009, p. 10)] can be the contributing factor for lower number of women candidates receiving tickets to stand in the election. Hindu women's struggle for freedom is not only limited to the national political issues but it also expanded at the local level. 
The local activism of Hindu women is also very well noted which was ignored in the past. Nepali women have played an active role in the recent past in tackling the issues through women's groups like a) ban in drinking and making alcohol in villages, b) safer motherhood, c) women ploughing the farm in absence of male members, though they were forbidden even to touch a plough before, d) wearing red clothes by widows, e) giving fire in death rituals, etc. All these actions of women groups have challenged the patriarchic Hinduized roles and norms (Shah, 2004; Basnet, 2007). The revolt of Durga Devi can also be taken as an example of women's local activism. Aziz (2001) narrated, “A widow with no formal education was intent on using government, not bribes or tricks, to secure her rights. She was confrontational in most of her dealings with people, and this was unacceptable to the culture" (pp. 102-103). There may be many undocumented cases of Hindu women who are fighting against the distorted Hindu patriarchy in Nepal. Unlike for non-Hindu women, these issues were major concerns for Hindu women as they were either restricted through or victim of such rituals. Movement of $\mathrm{Badi}^{9}$ in Nepal is a recent example of such a movement. Of late, more women are coming in politics, development, and security services and mostly the Hindu women are taking lead in each of these arenas. As a result of local movements and their political participation, Nepali women succeeded in shifting their identity as less productive to productive sector.

\section{Nepali Hindu Women's Move to the Productive Sector}

Nepali (Hindu) women often remained as oppressed Aimai but they have been fighting against patriarchy and are slowly gaining a semi-egalitarian status of Nepali Mahila. This status is being gained by women by daring to cross the Laxman Rekha - line of controlthrough political activism, participation in development and engaging in non-traditional productive sector. As a result of the continuous pressure of the women movement, the government has taken some positive initiatives for women's economic and social security. One of the initiatives taken by the government is the Country Code (11th Amendment) Bill 1997 which made the provisions in line with Supreme Court's verdict which has recognized daughters equal to son (Malla, 2001). Furthermore, Government of Nepal 2006/07 directive waived land registration fees for the land registered in the name of women, the disabled, and members of disadvantaged groups. Women's access to land has been raised from $10.8 \%$ in 2001 to $19.7 \%$ in 2011 (CBS, 2011). Along with the introduction of planned development initiatives in Nepal, Government of Nepal introduced Mother's Group approach to organize and benefit women in rural communities from development interventions. Mother's Group formed in 1970s primarily focused on celebrating festivals, organizing worship programs, improving the public water taps, etc. that are taken as the work of Mahila (Shah, 2004). Eventually, the gendered function of women's role in development moved towards more competitive development actors - bikase mahila- in Nepal. 
It is evident that government policy can be helpful to increase women's power in private as well as public domains. Recognizing the inherent power of women and also understanding the emerging wave of women's active role in society, Swami Vivekananda has predicted that the 21 st century will be the century of women (Jha, 2007). In the past, women's access to property was only limited to Stridhan like daijo and pewa ${ }^{10}$. Currently, we can see a number of women owning their own enterprises and employing women and thus moving from dependency to independence. For example, some women like that of Dibya Koirala not only organized women but also started providing cotton weaving skill for women to engage them in a productive sector (Thapa, 2008). Supplementing to and for women's activism and political socialization, women's increased gyana (literacy and education) is another important contributing factor for women's liberation in Nepal.

\section{Educated Women - Padhelekheka Mahila}

Nepali Hindu women are increasingly gaining formal and non-formal education (gyana) (Acharya, 2004) and gradually heading towards liberation since education is considered a means of liberation. The liberation movements are manifested in different forms and the role of educated women is noteworthy (Dahal, 2004). Though education was not equally accessible to men and women and therefore became a new force for perpetuating gender inequality in Nepal (Acharya, 2012), it has made many positive contributions to challenging various gender disparities. Moreover, the overall picture for gendered enrollment trends in Nepal is very positive (Terry \& Thapa, 2012, p.19).

Earlier, women were prohibited to study the Vedas, work as priest, and chant the Gayatri Mantra (Koirala, 2003). In the modern history of Nepal, Hinduism was taken as the foundation of education system and "literacy in Nepal followed the Hindu Varnashramic caste line" (Acharya, 2004). Education glorified Hindu values following the Wood's Education Policy fostering Hinduism as only the Religion of Nepal and implanting a false concept of King as the incarnation of Lord Vishnu (Caddell, 2007). However, through the structure and women's agency, women's access to education in post 1950s fostered women's intergenerational positive changes (Mishra, 2012). Educated women have been playing a vital role in women's movement by mobilizing other women and also invoking the idea of modernity, human rights and democracy so that their status in society can be improved (Dahal, 2004). Literacy not only helped women to understand their traditional roles but also helped them reduce dependency (Pokherel, 2012). Increasingly the literate and educated women are leading women's movement in Nepal.

Due to the increased access to education, and continued political and local activism, the government of Nepal made policies that created opportunities for Hindu women gaining better status in the society as productive and educated women. This has greatly facilitated to build a situation where traditional and cultural norms created by patriarchic Hinduism have been challenged. 


\section{Conclusion}

Through continuous movement against patriarchy Nepali Hindu women succeeded to make some space in political and social arena, their movement is not very much focused against religious and cultural aspects as it was rightly started by Yogmaya in early 19th century. Largely, women's movement is focused on socio-political and economic reform (Wydra, Jay, Johnson, Draper, Escobosa, \& Maurseth, 2010). Hindu women's movement supported by their social and political movement against oppression (karma) and increased education and literacy (gyana) prepared a ground for starting transformative movement in Nepal. So far, some Nepali women, who have been able to occupy some space in education, politics and wealth, are succeeded to change their less-valued condition - Aimai - to the improved condition -Mahila. However, a large number of women are still living as Aimai as they lack basic education, wealth and political space. Women's political movement, literacy and access to some productive resources are insufficient mainly for transforming the patriarchic Hinduism - the major barriers of women's liberation in Nepal. Despite few positive changes in the lives of Nepali Hindu women, mukti is still a far-off status as they have to pass through a long thorny path of liberation.

\section{Notes}

${ }^{1}$ Mukti is derived from the Sanskrit word 'Mokshya' that represents the desire of Hindu community to be liberated themselves from the world of troubles and reach the stage of greater freedom which can be acquired through devotion (Dhyana), knowledge (Gyanaa), and action (Karma). This concept is derived from a story of the Mahabharata where Lord Krishna was convincing Arjuna (a great warrior) to fight with his own relatives for the sake of Dharma.

${ }^{2}$ The Rig Veda is the oldest known to Sanskrit literature and it was developed in the classical period and is also known as the most sacred (Young, 2002). It is a holy book of Hindu Religion that consists of hymns to various deities.

${ }^{3}$ Hindu women particularly those categorized as untouchables are heavily deprived and this is widely applied to all Hindu women during their menstruation period (4 days a month), in the period of child birth (Sutkeri). Married, uneducated women who don't get married within a certain age, disabled, having issue of infertility, etc. face more oppression than other women in Nepal.

${ }^{4}$ The Manusmriti basically comprises the Laws of Manu written in the 2nd century. It is a Hindu religious scripture to regulate Hindu code and Dharma (religion). "A virtuous wife should never do anything displeasing to the husband who took her in marriage, when he is alive or dead, if she longs for her husband's world (after death). [157] When her husband is dead she may fast as much as she likes, (living) on auspicious flowers, roots, and fruits, but she should not even mention the name of another man. She should be long-suffering until death, self-restrained, and chaste, striving (to fulfill) the unsurpassed duty of women who have one husband...[165] The woman who is not unfaithful to her husband and who restrains her mind, speech, and body reaches her husband's world (after death), and good people call her a virtuous woman... (115-116)" (as cited in LohaniChase, 2008). 
${ }^{5}$ Widow burning on the funeral pyre of their husband is known as sati system in Nepal which is not in practice now.

${ }^{6}$ Dalit were classified as the lowest strata of Hindu community, they are mainly the manual workers and also considered as untouchables. Despite the law prohibited, even today they are discriminated in Hindu societies.

${ }^{7}$ The new constitution promulgated in 1990 made mandatory that all the contending Parties file a minimum of 5 percent of the seats for women as a condition to contest the election.

${ }^{8}$ Though in 2013 CA Election, less number of women elected in compare with 2008 but the total percent of women in CA will be remained about 30 percent of 601 members of CA in Nepal.

${ }^{9}$ Badi community originally came to Nepal from India in the 14th century and settled in Salyan district. Their primary responsibility is to be entertainer staging song and dance but gradually they also started/are trapped in prostitution (Coax, 1993). The Badi communities are residing in the mid and far west Nepal and they are Hindus by religion.

${ }^{10}$ Daijo is commonly translated as dowry that is sent along with the bride whereas pewa is small property given by the parental home.

\section{References}

Acharya, M. (2012). Affirmative action for gender equality and inclusion. Kathmandu: UN Women and UNICEF.

Acharya, S. (2004). Democracy, gender equality and women's literacy: Experience from Nepal. Kathmandu: UNESCO.

Adams, B. N., \& Sydie, R. A. (2009). Sociological theory. New Delhi: Vanisagar Publication.

Awasthi, L. D. (2004). Exploring monolingual school practices in multilingual Nepal

(Unpublished doctoral dissertation). The Danish University of Education, Copenhagen, Denmark.

Aziz, B. N. (2001). Heir to a silent song: Two rebel women of Nepal. Kathmandu: Centre for Nepal and Asian Studies, Tribhuvan University.

Basnet, S. (2007). Displaced war widows of post armed conflict in Nepal (Research Brief No.

04). Kathmandu: Social Inclusion Research Fund. Retrieved from www.socialinclusion.org.np/new/files/5765_12Syaron_Basnet_1336478585dGZd.pdf

Barnes, B. J. (2002). Women and Buddhism in India. In A. Sharma (Ed.), Women in Indian religions (pp. 38-69). New Delhi: Oxford University Press.

Bennett, L. (2002). Dangerous wives and sacred sisters: Social and symbolic roles of highcaste women in Nepal. Kathmandu: Mandala Publications.

Bennett, L. (2005). Gender caste and ethnic exclusion in Nepal: Following the policy process from analysis to action. Paper presented at the Arusha Conference, "New Frontiers of Social Policy", December 12-15, Arusha, Tanzania. Retrieved from siteresources.worldbank.org/INTRANETSOCIALDEVELOPMENT/Resources/Bennett.r ev.pdf 
Central Bureau of Statistics. (2011). Nepal population and housing census, 2011. Kathmandu: Author.

Caddell, M. (2007). Education and change: A historical perspective on schooling, development and the Nepali nation-state. In K. Kumar \& J. Oesterheld (Eds.). Education and social change in South Asia (pp. 251-284). New Delhi: Orient Longman.

Chawala, J. (1992). The mythic origins of the menstrual taboo in the Rig Veda. Retrieved from http://www.matrika-india.org/Research/MythicOrigins.html

Chu, M. (1996). The power of metaphor: Veils within Judeo-Christianity and Islam. Retrieved from http://www.artpoetryfiction.com/essays/chu/veilsbody.html

Coax, T. (1993). The Badi: Prostitution as a social norm among an untouchable caste of west Nepal. Kailash, 16(3\&4), 165-186. Retrieved from http://himalaya.socanth.cam.ac.uk/collections/journals/kailash/pdf/kailash_ 16_0304_02.pdf

Dahal, D. R. (2004). New social movements in Nepal. Retrieved from http://www.nepaldemocracy.org/civic_education/Social\%20Movements.pdf

Election Commission. (2014). Election results- 2014. Retrieved from http://www.election.gov.np/election/np

Falahi, N. F. (2004). Quran Mazid (Trans. M. A. A. Falahi). Kathmandu: Islami Sangh Nepal.

Gewali, S. B. (Ed.). (1954). Bhanubhakta ko Ramayana [The Ramayana of Bhanubhakta]. Kathmandu: Pasupat Yantralaya.

National Planning Commission. (2010). Three year's approach paper. Kathmandu:Author. Halder, D., \& Jaishankar, K. (2009). Property rights of Hindu women: A feminist review of succession laws of ancient, medivial, and modern India. Journal of Law and Religion, 24(2), 663-687.

Indian Express. (2012, December 19). Hinduism third largest religion of world: Pew research. Retrieved from http://www.indianexpress.com/news/hinduism-third-largestreligion-of-world-pew-research/1047536/

Jha, R. (2007). Women and the Vedas. Retrieved from http://www.ivarta.com/columns/OL_070503.htm

Karki, K. (2009). Women's political struggle in Nepal: A shared history of South Asia. Retrieved from http://www.articlesbase.com/history-articles/womens-political-strugglein-nepal-a-shared-history-of-south-asia-962970.html

Khezerloo, R. (2002). Working at Derrida: The happy union of deconstruction and feminism. Urima, Iran: Urmia University.

Koirala, C. (2003). Cultural determinants on girl's education. Unpublished manuscript. Kondos, V. (2004). On the ethos of Hindu women: Issues, taboos and forms of expression. Kathmandu: Mandala Publications. 
Lawoti, M. (2010). Informal institutions and exclusion in democratic Nepal. In M. Lawoti, \& A. Guneratne (Eds.), Ethnicity, inequality, and politics in Nepal (18-54). Kathmandu: The Himalaya Series in Nepal Studies.

Lohani-Chase, R. S. (2008). Women and gender in the Maoist people's war in Nepal: Militarism and dislocation (Unpublished doctoral dissertation). Graduate School-New Brunswick Rutgers, The State University of New Jersey.

Manusmriti. (n.d.). Manusmriti: The laws of Manu 1500 B.C. (G. Buhler, Trans.). Retrieved from http://sanskritdocuments.org/all_pdf/manusmriti.pdf

Malla, M. V. (2011). Political socialization of women in Nepal. New Delhi: Adroit Publishers.

Malla, S. (2001). Property right of Nepalese women. Kathmandu: Friedrich Ebert Stiftung, Nepal. Retrieved from 12/3/2013 from http://www.nepaldemocracy.org/ gender/property_rights

Misra, C. (2010). Badalido Nepali samaj [Changing Nepali society] Kathmandu: Fineprint IANC.

Mosher, S. W. (2007). President's page: Let us ban sex-selective abortions. PRI Review, 17(2). Retrieved from http://pop.org/content/presidents-page-let-us-ban-sex-selective1340

Mongbay. (2013). Nepal: The 1986 elections. Retrieved from http://www.mongabay.com/history/nepal/nepal-the_1986_elections.html

Neupane, G., (2004). Upheavals in Nepal - Transforming the state and society. Kathmandu: Center for Development Studies. Retrieved from http://neupaneg.wordpress.com/2010/10/07/upheavals-in-nepal-transforming-the-stateand-society

O’Neil, D. (2006). What is culture? Retrieved from http://anthro.palomar.edu/culture/culture_1.htm

Onta, P. (1996). Ambivalence denied: The making of rastriya itihas in Panchayat era textbooks. Contribution to Nepalese Studies, 23(1), 123-254.

Pettigrew, J., \& Shneiderman, S. (2004). Women in the maobaadi: Ideology and agency in Nepal's maoist movement. Retrieved from

http://www.himalmag.com/component/content/article/4272-women-in-the-maobaadiideology-and-agency-in-nepals-maoist-movement.html

Pokharel, U. (2012). Women empowerment through literacy class (Unpublished master's dissertation). Kathmandu University. Dhulikhel, Nepal.

Pottenger, J. (2010). The things Paul said. Revisions: A Journal of Christian Perspectives, $6(1), 4-5$.

Pradhan, K. (2013). Regression of women in CA II election. Retrieved from http://kishorpradhan.wordpress.com/2013/12/03/regression-of-women-in-ca-ii-election/ Ritzer, G. (2000). Sociological theory (5th ed.). Singapore: McGrow-Hill. 
Renaissance Society Nepal. (2009). Women's political participation, empowerment and inclusions in Nepal: Survey report and strategic action plan. Bhaktapur: Author \& UNIFEM.

Sachedina, A. (2003). Globalization, religion and women. Critical Half, 1(1), 11-14.

Sen, M. K. (1961). Hinduism. London: Penguin Publication.

Sered, S. S. (2011). Women, religion, and modernization: Tradition and transformation among elderly Jews in Israel. In S. Brettell \& C. F. Sargent (Eds.), Gender in crosscultural perspective (5th ed.). New Delhi: PHI Learning.

Shah, S. (2004). A project of memoreality: Transnational development and local activism among rural women in Nepal (Unpublished doctoral thesis). Harvard University, Cambridge, USA.

Sharma, A. (2002). Women in Indian religions. New Delhi: Oxford.

Shrestha, M. (2011). Relevance of women reservation in Nepal. Academic Voices, 1(1), 3438.

Singhal, A. (2006). Ashok Singhal and relevance of manusmriti. Retrieved from http://sangh.wordpress.com/2006/04/20/test/

Stivachtis, Y. A., \& Georgakis, S. (2008). Emancipation or liberation? The European Union's gender policy and candidate states - The case of Turkey. Multicultural, Gender and Minority Studies, 3(1), 1-18.

Suwal, E. (2013, August, 02). An impending loss. The Republica Daily. Retrieved from http://www.myrepublica.com/portal/index.php?action=news_details\&news

Terry, G., \& Thapa, N. (2012). Gender audit of Nepal's school sector reform programme.

Cambridge: DFID Human Development Resource Centre.

Thapa, A. (2012, March 10). Rewriting women's histories. The Kathmandu Post. Retrieved from http://www.ekantipur.com/the-kathmandu- post/2012/03/09/

related_articles/rewriting-womens-histories/232452.html

Thapa, A. (2010, October 08). The duality that is Durga. ekantipur. Retrieved from http://www.ekantipur.com/the-kathmandu-post/2010/10/08/features/the-duality-that-isdurga/213672/

Thapa, M. (Oct-Dec, 2008). Nepali mahila andolan ma asmita [Asmita in Nepali Women's Movement]. Asmita Bi-monthly, 66. Kathmandu: Dhaulagiri Press.

The Women's CAUCUS of the Constituent Assembly of Nepal. (2012). In IDEA (Trans.), Women's rights and agenda to be incorporated in the new constitution (pp. 14-28).

Kathmandu: Author.

UNESCO. (2001). Report on the state of women in urban local government Nepal.

Kathmandu: Author.

UNDP. (2010). Report on gender mapping in the field of elections. Kathmandu: Author.

Varun, P. (2006). Sati pratha and its origins. Retrieved from

http://www.ivarta.com/columns/OL_060328.htm

Journal of Education and Research, March 2014, Vol. 4, No. 1 
Verter, B. (2003). Spiritual capital: Theorizing religion with Bourdieu against Bourdieu. Sociological Theory, 21(2), 150-174.

World Economic Forum. (2013). The global gender gap report, 2013. Geneva: Author.

Wydra, M., Jay, S., Johnson, T., Draper, A., Escobosa, E., \& Maurseth, A. (2010).

Empowering women in Nepal: A 2010 report. Retrieved from

http://pages.uoregon.edu/aweiss/int1442_542/Nepal-Empowering\%20Women.pdf

Yami, H. (2010). Women's role in the Nepalese movement: Making a people's constitution.

Retrieved from http://monthlyreview.org/commentary/womens-role-in- the-nepalesemovement

Young, K. K. (2002). Women and Hinduism. In A. Sharma (Ed.), Women in Indian religions (pp. 3-37). New Delhi: Oxford University Press. 